\title{
Accuracy of the estimates of ammonia concentration in rumen fluid using different analytical methods
}

\author{
[Exatidão das estimativas de concentração de amônia em fluido ruminal utilizando \\ diferentes métodos analíticos] \\ N.K.P. Souza ${ }^{1}$, E. Detmann ${ }^{2 *}$, S.C. Valadares Filho ${ }^{2}$, V.A.C. Costa ${ }^{3}$, D.S. Pina ${ }^{1}$, \\ D.I. Gomes ${ }^{4}$, A.C. Queiroz ${ }^{2}$, H.C. Mantovani ${ }^{2}$ \\ ${ }^{1}$ Universidade Federal de Mato Grosso - Sinop, MT \\ ${ }^{2}$ Universidade Federal de Viçosa - Viçosa, MG - Pesquisador do CNPq \\ ${ }^{3}$ Universidade Estadual do Norte Fluminense-Campos dos Goytacazes, RJ \\ ${ }^{4}$ Universidade Federal Rural da Amazônia - Parauapebas, PA
}

\begin{abstract}
The accuracy of two different methods in measuring the ammonia nitrogen $\left(\mathrm{N}-\mathrm{NH}_{3}\right)$ concentration in rumen fluid were evaluated: a catalyzed indophenol colorimetric reaction (CICR) and the Kjeldahl distillation (KD). Five buffered standard solutions containing volatile fatty acids, true protein, and known ammonia concentrations $\left(0,3,6,12\right.$, and $\left.24 \mathrm{~N}-\mathrm{NH}_{3} \mathrm{mg} / \mathrm{dL}\right)$ were used to simulate rumen fluid. Different ratios $(10: 1,7.5: 1,5: 1,2.5: 1,1: 1,1: 2.5,1: 5,1: 7.5$, and 1:10) of a potassium hydroxide solution $(\mathrm{KOH}, 2$ $\mathrm{mol} / \mathrm{L})$ to standard solutions were evaluated by the KD method. The accuracy of each method was evaluated by adjusting a simple linear regression model of the estimated $\mathrm{N}-\mathrm{NH}_{3}$ concentrations on the $\mathrm{N}$ $\mathrm{NH}_{3}$ concentrations in the standard solutions. When the KD method was used, $\mathrm{N}-\mathrm{NH}_{3}$ was observed to be released from the deamination of true protein $(\mathrm{P}<0.05)$, and an incomplete recovery of $\mathrm{N}-\mathrm{NH}_{3}$ was observed $(\mathrm{P}<0.05)$, except for 7.5:1 and 5:1 ratios of $\mathrm{KOH}$ solution to standard solutions $(\mathrm{P}>0.05)$. The estimates of the $\mathrm{N}-\mathrm{NH}_{3}$ concentration obtained by the CICR method were found to be accurate $(\mathrm{P}>0.05)$. After the accuracy evaluation, ninety-three samples of rumen fluid were evaluated by the CICR and KD methods (using the 5:1 ratio of $\mathrm{KOH}$ solution to rumen fluid sample), assuming that the CICR estimates would be accurate. The $\mathrm{N}-\mathrm{NH}_{3}$ concentrations obtained by the two methods were observed to be different $(\mathrm{P}<0.05)$ but strongly correlated $(\mathrm{r}=0.9701)$. Thus, it was concluded that the estimates obtained by the Kjeldahl distillation using a 5:1 ratio of $\mathrm{KOH}$ solution to rumen fluid sample can be adjusted to avoid biases. Furthermore, a model to adjust the $\mathrm{N}_{-} \mathrm{NH}_{3}$ concentration is suggested.
\end{abstract}

Keywords: ammonia nitrogen, indophenol colorimetric reaction, Kjeldahl distillation

\section{RESUMO}

Avaliou-se a exatidão de dois métodos para mensuração da concentração de nitrogênio amoniacal $(N$ $\mathrm{NH}_{3}$ ) em fluido ruminal: reação colorimétrica catalisada por indofenol (RCCI) e destilação de Kjeldahl (DK). Cinco soluções-tampão contendo ácidos graxos voláteis, proteína verdadeira e concentrações conhecidas de amônia $\left(0,3,6,12\right.$ e $\left.24 \mathrm{~N}-\mathrm{NH}_{3} \mathrm{mg} / \mathrm{dL}\right)$ foram utilizadas para simular o fluido ruminal. Diferentes relações $(10: 1 ; 7,5: 1 ; 5: 1 ; 2,5: 1 ; 1: 1 ; 1: 2,5 ; 1: 5 ; 1: 7,5$ e 1:10) entre a solução de hidróxido de potássio $(\mathrm{KOH}, 2 \mathrm{~mol} / \mathrm{L})$ e as soluções-padrão foram avaliadas no método $\mathrm{DK}$. A exatidão de cada método foi avaliada por intermédio do ajustamento de um modelo de regressão linear simples das concentrações estimadas de $\mathrm{N}-\mathrm{NH}_{3}$ sobre as concentrações reais de $\mathrm{N}-\mathrm{NH}_{3}$ nas soluções-padrão. Com a utilização da $\mathrm{DK}$ observou-se que $\mathrm{N}-\mathrm{NH}_{3}$ foi liberada a partir da deaminação de proteína verdadeira $(P<0,05)$. Adicionalmente, a utilização da DK promoveu recuperação incompleta da $N-N_{3}(P<0,05)$,

Recebido em 11 de abril de 2012

Aceito em 13 de junho de 2013

*Autor para correspondência (corresponding author)

E-mail: detmann@ufv.br

Apoio: CNPq, FAPEMIG (PPM) e INCT-Ciência Animal 
com exceção das razões entre a solução de KOH e as soluções-padrão de de 7,5:1 e de 5:1 (P>0,05). As estimativas de concentração de amônia obtidas por intermédio do método de RCCI foram exatas $(P>0,05)$. Após a avaliação da exatidão, noventa e três amostras de fluido ruminal foram avaliadas por intermédio dos métodos de RCCI e de DK (neste caso usando a razão entre solução de KOH e fluido ruminal de 5:1). Nesta avaliação assumiu-se que as estimativas obtidas com a RCCI seriam exatas. Observou-se que as concentrações de $\mathrm{N}-\mathrm{NH}_{3}$ obtidas pelos dois métodos foram diferentes $(P<0,05)$, mas fortemente correlacionadas $(r=0,9701)$. Concluiu-se que as estimativas obtidas com a DK utilizando-se razão entre a solução de $\mathrm{KOH}$ e a amostra de fluido ruminal de 5:1 poderiam ser ajustadas para correções de vieses Um modelo para realização desse ajustamento foi sugerido.

Palavras-chave: destilação de Kjeldahl, nitrogênio amoniacal, reação colorimétrica de indofenol

\section{INTRODUCTION}

Several parameters have been suggested for evaluating the availability of dietary nitrogenous compounds in the rumen. To date, the concentration of the ammonia nitrogen $\left(\mathrm{N}-\mathrm{NH}_{3}\right)$ has been used as a qualitative reference to understand the adequacy of the rumen environment according to the microbial activity on fibrous carbohydrates (Detmann et al., 2009). This strategy is possibly associated with the fact that $\mathrm{N}-\mathrm{NH}_{3}$ is the preferred nitrogen source for the growth of fibrolytic microorganisms (Russell, 2002).

Thus, considering the relevance of $\mathrm{N}^{-\mathrm{NH}_{3}}$ in ruminant nutrition, the methods used to evaluate its concentration in the ruminal fluid ought to provide accurate estimates.

Chaney and Marbach (1962) have proposed a method for $\mathrm{N}-\mathrm{NH}_{3}$ evaluation in biological fluids that is based on a catalyzed indophenol colorimetric reaction (CICR), and this method is intensely used in microbiological assays (e.g., Thomas and Russell, 2004). Alternatively, Fenner (1965) has established the theoretical basis for $\mathrm{N}^{-\mathrm{NH}_{3}}$ evaluation in rumen fluid by steam distillation in the presence of a potassium hydroxide solution. This basis has been adapted for use in the Kjeldahl distillation (KD) procedure, which has been used in several ruminant nutrition assays (e.g., Detmann et al., 2009; Souza et al., 2010; Costa et al., 2011). Nonetheless, no study has compared the accuracy of these methods in the estimation of $\mathrm{N}-\mathrm{NH}_{3}$ contents.

Therefore, the objective of this work was to evaluate the accuracy of $\mathrm{N}-\mathrm{NH}_{3}$ concentration estimates in rumen fluid with the $\mathrm{KD}$ and the CICR methods.

\section{MATERIAL AND METHODS}

The experiment was conducted at the Animal Nutrition Laboratory of the Animal Science Department at the Universidade Federal de Viçosa in Viçosa, Brazil.

To evaluate de accuracy of the methods, five standard solutions containing different $\mathrm{N}-\mathrm{NH}_{3}$ concentrations were used to evaluate the accuracy of the estimates obtained from the two methods. Those five solutions were produced to simulate rumen fluid characteristics.

The basal solution was constituted by a buffer solution whose $\mathrm{pH}$ had previously been adjusted to 6.8 by flushing with $\mathrm{CO}_{2}$ (McDougall, 1949). Acetic acid (Sigma-Aldrich 320099; 60mmol/L), propionic acid (SigmaAldrich 402907; 30mmol/L) and butyric acid (Sigma Aldrich B103500; 10mmol/L) were added to the solution to represent the volatile fatty acids (VFA) present in the rumen fluid. Additionally, casein hydrolysate (Fluka 2209; $3 \mathrm{~g} / \mathrm{L}$ ) was added to simulate the true protein content of the rumen fluid, and thimerosal (Sigma 8784; 50mg/L) was used to prevent microbial growth. The solution was divided into five aliquots, and known quantities of ammonium chloride $\left(\mathrm{NH}_{4} \mathrm{Cl}, \mathrm{PA}, \mathrm{ACS}\right.$, Vetec 113) were added to provide $0,3,6,12$, and 24 mg N-NH $3 /$ dL.

The evaluation of the $\mathrm{N}-\mathrm{NH}_{3}$ concentration by the CICR method was performed according to the descriptions of Chaney and Marbach (1962). Aliquots of $10 \mu \mathrm{L}$ of the standard solutions were poured into glass tubes, and $1.5 \mathrm{~mL}$ of a phenol solution $(50 \mathrm{~g} / \mathrm{L}$ of phenol and $0.25 \mathrm{~g} / \mathrm{L}$ of sodium nitroprusside) plus $1.5 \mathrm{~mL}$ of sodium hypochlorite solution $(16.9 \mathrm{~mL} / \mathrm{L}$ of sodium hypochlorite and $25 \mathrm{~g} / \mathrm{L}$ of sodium hydroxide) 
were added. The tubes were stirred by vortexing and kept in a water bath at $39^{\circ} \mathrm{C}$ for 15 minutes. The absorbance was then read at $630 \mathrm{~nm}$ in a spectrophotometer UV/Visible BEL Photonics 2000 UV. A standard curve was generated according to Chaney and Marbach (1962).

To evaluate the $\mathrm{N}-\mathrm{NH}_{3}$ concentration according the KD method, 5-mL aliquots of standard solutions were poured into glass tubes that were coupled in a Kjeldahl distillator (Tecnal ${ }^{\circledR}$ TE 036/1). Potassium hydroxide solution $(\mathrm{KOH}$, $2 \mathrm{~mol} / \mathrm{L}$; Fenner, 1965) was then added, and the material was distilled in a boric acid solution $(40 \mathrm{~g} / \mathrm{L})$. The solution obtained from the distillation (approximately $100 \mathrm{~mL}$ ) was titrated with hydrochloric acid $(\mathrm{HCl} ; 0.005 \mathrm{~N})$. Methyl red and bromocresol green were added to the boric acid solution and used as indicators. Different ratios of the $\mathrm{KOH}$ solution to the standard solutions were evaluated $(10: 1,7.5: 1$, $5: 1,2.5: 1,1: 1,1: 2.5,1: 5,1: 7.5$, and $1: 10)$

The $\mathrm{N}-\mathrm{NH}_{3}$ concentration was estimated as follows:

$N-N H_{3}=\frac{V \times 0.005 \times f \times 14 \times 100}{A}$

where $\mathrm{N}-\mathrm{NH}_{3}=$ the ammonia nitrogen concentration $(\mathrm{mg} / \mathrm{dL}), \mathrm{V}=$ the volume of hydrochloric acid $(\mathrm{mL}), f=$ the factor for the correction of the hydrochloric acid concentration obtained with a $\mathrm{Na}_{2} \mathrm{CO}_{3}$ solution $(0.005 \mathrm{~N}), 14=$ the atomic weight of nitrogen, and $\mathrm{A}=$ the aliquot volume $(\mathrm{mL})$.

Five replicates for each standard solution were evaluated by both the CICR method and KD method at different $\mathrm{KOH}$ :standard solution ratios.

After accuracy evaluation, a laboratorial assay was performed to compare the estimates obtained by the methods in rumen fluid samples.

Ninety-three rumen fluid samples were obtained from cattle under grazing conditions, receiving nitrogen supplementation (true protein and/or non-protein nitrogen) during 2008. Those samples were taken at different times during the day and filtered through three layers of cheesecloth. For each sample, a 100-mL aliquot was then separated, fixed with $2.5 \mathrm{~mL} \mathrm{H}_{2} \mathrm{SO}_{4}$ (1:1) and frozen at $-20^{\circ} \mathrm{C}$ (Costa et al., 2011).
After thawing, a 50-mL aliquot of each sample was poured into a centrifuge tube, $0.5 \mathrm{~mL}$ of a trichloroacetic acid solution $(100 \mathrm{~g} / \mathrm{L})$ was added, and the sample was slowly stirred. The material was allowed to settle at room temperature for 30 minutes after which, the material was centrifuged at $1,000 \times \mathrm{g}$ for 10 minutes. The supernatant was analyzed in duplicate by the CICR method and $\mathrm{KD}$ method using the $\mathrm{KOH}$ :rumen fluid ratios of 5:1 and $1: 10$.

The accuracy of the $\mathrm{N}-\mathrm{NH}_{3}$ concentrations obtained by the CICR and KD methods was evaluated by adjusting a simple linear regression equation of estimated values (dependent variable) on the $\mathrm{N}-\mathrm{NH}_{3}$ content in standard solutions (independent variable); the statistical analysis was conducted under the null hypotheses below:

$H_{0}: \beta_{0}=0$

$H_{0}: \beta_{1}=1$

where $\beta_{0}=$ intercept, and $\beta_{1}=$ slope.

The $\mathrm{N}-\mathrm{NH}_{3}$ contents were considered to be accurate when both of the null hypotheses were not rejected.

Additionally, the $\mathrm{N}-\mathrm{NH}_{3}$ contents in the rumen fluid samples were compared by adjusting a simple linear regression equation of the values estimated by the KD method (dependent variable) on the values estimated by the CICR method (independent variable). The statistical analysis was conducted under the null hypotheses expressed by equations (2a) and (2b). The estimates were considered to be similar if both of the null hypotheses were not rejected.

All of the statistical procedures were performed using the PROC REG of SAS (Statistical Analysis System, version 9.1) $(\alpha=0.05)$.

\section{RESULTS}

With the KD method, the intercept estimates were observed to be different from zero $(\mathrm{P}<0.05)$ for all of the ratios of $\mathrm{KOH}$ solution to standard solutions (Table 1). Additionally, as the $\mathrm{KOH}$ proportion decreased, the estimates of the $\mathrm{N}-\mathrm{NH}_{3}$ concentrations in the blank standard solution $(0$ $\mathrm{mg} \mathrm{N}-\mathrm{NH}_{3} / \mathrm{dL}$ ) and the intercept estimates also decreased (Table 2 and Figure 1). 
Table 1. Estimates of the linear regression parameters for the relationship between the $\mathrm{N}-\mathrm{NH}_{3}$ concentrations obtained by two methods (dependent variable, $\mathrm{Y}$ ) and the true concentrations of $\mathrm{N}-\mathrm{NH}_{3}$ in the standard solutions (independent variable, $\mathrm{X}$ )

\begin{tabular}{|c|c|c|c|c|c|c|}
\hline \multirow[b]{2}{*}{ Method } & \multicolumn{2}{|c|}{ Regression parameter ${ }^{4}$} & \multirow[b]{2}{*}{$S_{X . Y^{5}}$} & \multirow[b]{2}{*}{$\mathrm{r}^{2}$} & \multicolumn{2}{|c|}{ P Value ${ }^{6}$} \\
\hline & Intercept & Slope & & & $\mathrm{H}_{0}: \beta_{0}=0$ & $\mathrm{H}_{0}: \beta_{1}=1$ \\
\hline \multicolumn{7}{|l|}{$\mathrm{KD}^{12}$} \\
\hline $10: 1$ & $2.601 \pm 0.045$ & $0.932 \pm 0.004$ & 0.156 & 0.9996 & $<0.001$ & $<0.001$ \\
\hline $7.5: 1$ & $2.489 \pm 0.179$ & $0.962 \pm 0.018$ & 0.590 & 0.9928 & $<0.001$ & 0.053 \\
\hline $5: 1$ & $2.284 \pm 0.242$ & $0.976 \pm 0.025$ & 0.798 & 0.9875 & $<0.001$ & 0.358 \\
\hline $2.5: 1$ & $2.097 \pm 0.034$ & $0.905 \pm 0.003$ & 0.116 & 0.9998 & $<0.001$ & $<0.001$ \\
\hline $1: 1$ & $1.479 \pm 0.070$ & $0.917 \pm 0.006$ & 0.242 & 0.9991 & $<0.001$ & $<0.001$ \\
\hline $1: 2.5$ & $1.053 \pm 0.053$ & $0.888 \pm 0.004$ & 0.179 & 0.9995 & $<0.001$ & $<0.001$ \\
\hline $1: 5$ & $0.808 \pm 0.052$ & $0.887 \pm 0.004$ & 0.179 & 0.9995 & $<0.001$ & $<0.001$ \\
\hline $1: 7.5$ & $0.693 \pm 0.055$ & $0.891 \pm 0.005$ & 0.186 & 0.9994 & $<0.001$ & $<0.001$ \\
\hline $1: 10$ & $0.569 \pm 0.120$ & $0.891 \pm 0.009$ & 0.409 & 0.9975 & $<0.001$ & $<0.001$ \\
\hline $\mathrm{CICR}^{3}$ & $0.688 \pm 0.369$ & $0.995 \pm 0.029$ & 1.264 & 0.9806 & 0.077 & 0.878 \\
\hline
\end{tabular}

${ }^{1}$ Kjeldahl distillation. ${ }^{2}$ Using different ratios of the KOH solution to the standard solutions (mL/mL). ${ }^{3}$ Catalyzed indophenol colorimetric reaction. ${ }^{4}$ Estimate \pm standard error. ${ }^{5}$ Standard deviation of the relationship between $\mathrm{X}$ and $\mathrm{Y}$. ${ }^{6}$ See more details about the hypotheses' test in Equation 2.

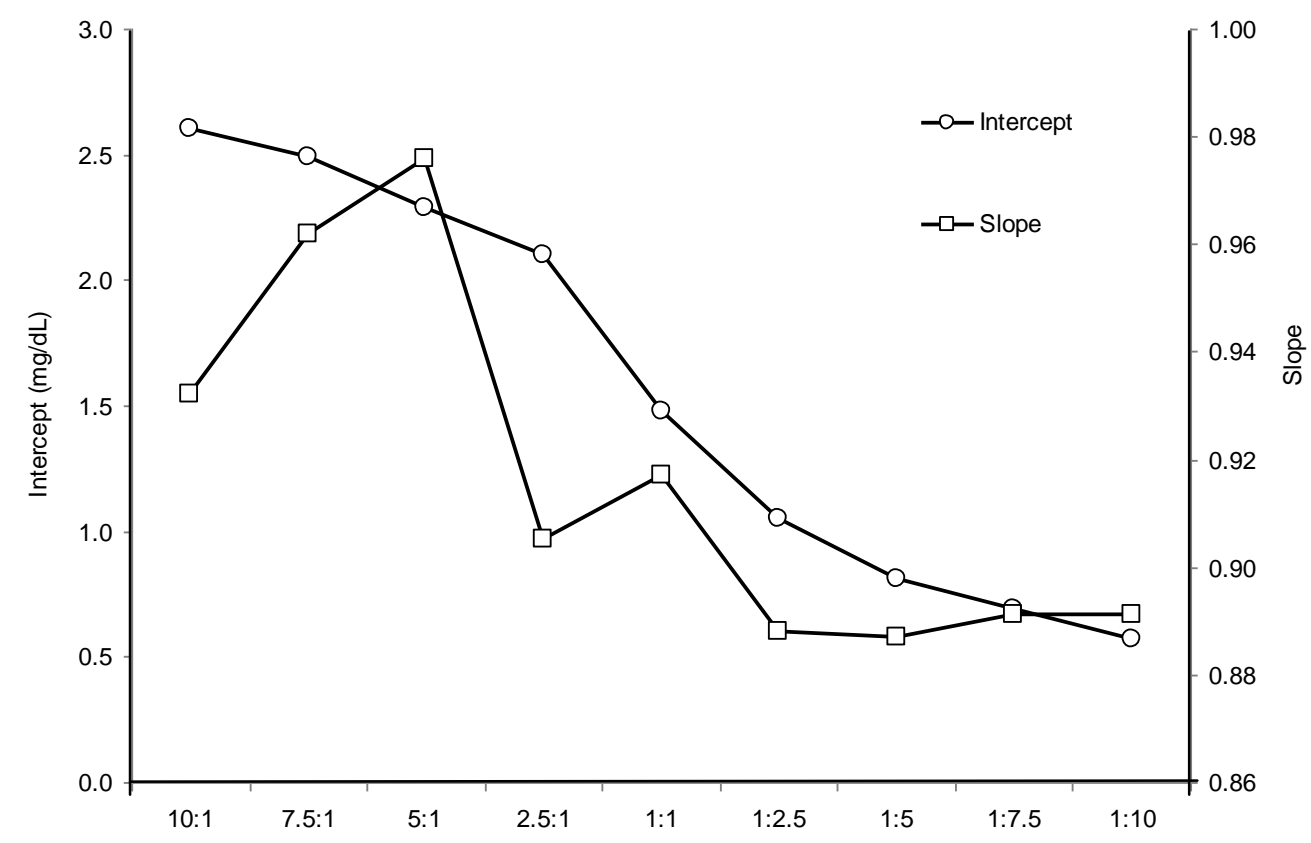

Figure 1. Estimates of the intercept and slope for the adjusted linear functions of the ammonia nitrogen concentrations obtained by the Kjeldahl distillation of standard solutions using different ratios of potassium hydroxide solution to standard solutions.

For the results obtained using the KD method, the slopes were found to be different from one $(\mathrm{P}<0.05)$, except for at the 5:1 and 7.5:1 ratios of $\mathrm{KOH}$ solution to the standard solutions (Table 1 and Figure 1).
The estimates of the $\mathrm{N}-\mathrm{NH}_{3}$ concentration obtained by the CICR method were found to be accurate $(\mathrm{P}>0.05$; Table 1$)$.

When rumen fluid samples were evaluated using the $\mathrm{KD}$ method, $\mathrm{N}-\mathrm{NH}_{3}$ was not detected at the 1:10 ratio of the $\mathrm{KOH}$ solution to the standard solutions. 
The relationship between the $\mathrm{N}-\mathrm{NH}_{3}$ concentrations obtained by the CICR and KD (5:1 ratio) methods presented an interception that was different from zero and slope different from

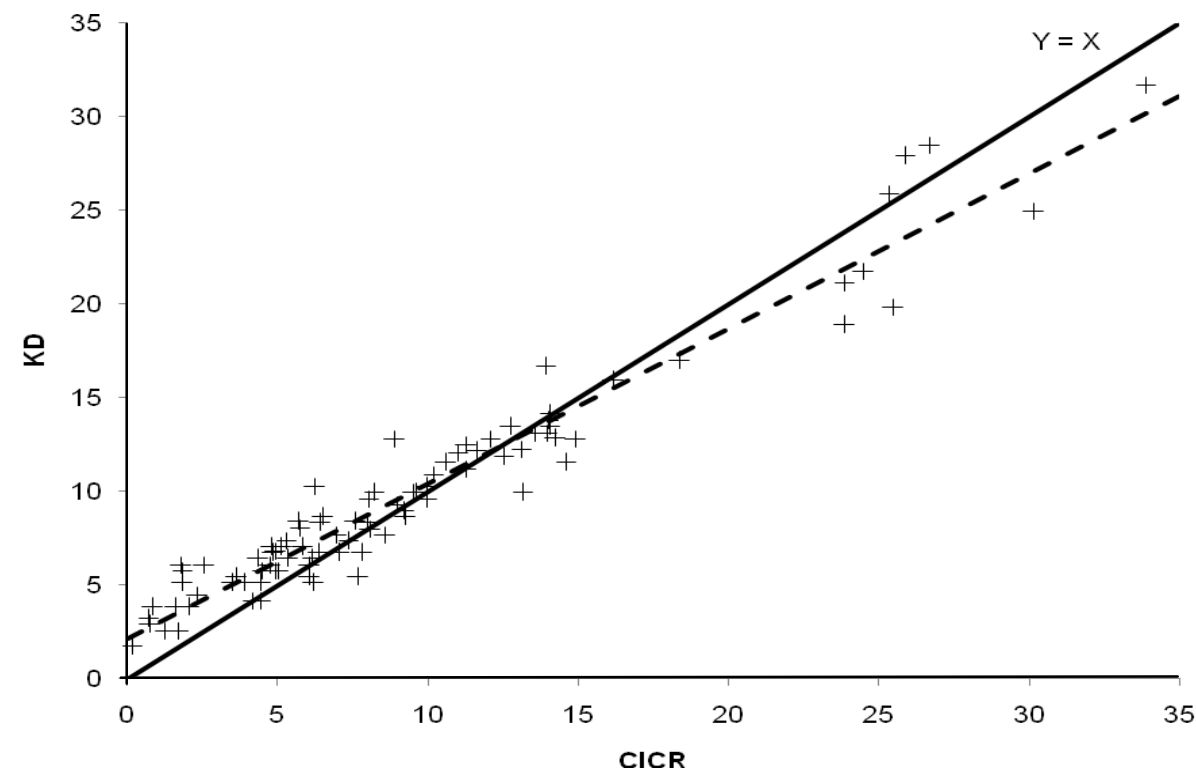

Figure 2. Relationship between the ammonia nitrogen concentrations $(\mathrm{mg} / \mathrm{dL})$ in rumen fluid samples estimated by the catalyzed indophenol colorimetric reaction (CICR) and Kjeldahl distillation (KD; 5:1) methods $\left[\hat{Y}=2.109 \pm 0.254+0.828 \pm 0.022 \times \mathrm{X} ; \mathrm{s}_{\mathrm{XY}}=1.47 ; \mathrm{r}^{2}=0.9410 ;\right.$ the dashed line represents the least squares straight line].

\section{DISCUSSION}

The quantity of the $\mathrm{KOH}$ solution used in the KD method must be sufficient to neutralize even extremely high concentrations of VFA; yet, the solution should remain weak enough to prevent the deamination of major amino acids (Fenner, 1965). The neutralization of VFA is assumed to be necessary to release the volatile bases. In other words, it is necessary to convert $\mathrm{NH}_{4}{ }^{+}$(that presents low volatility) into $\mathrm{NH}_{3}$, the volatile form of ammonia that can be easily steamcarried to the boric acid solution. In contrast, an excessive quantity of $\mathrm{KOH}$ can cause the hydrolysis of peptide bonds and the deamination of true protein, which would artificially increase the $\mathrm{N}-\mathrm{NH}_{3}$ concentration.

The pattern of intercept estimates in the KD method (Table 1) indicates that $\mathrm{KOH}$ promoted the release of ammonia nitrogen from amino acids, and the deamination intensity seems to be directly associated with the proportion of $\mathrm{KOH}$ in the distilled solution (Figure 1). one $(\mathrm{P}<0.05)$. Therefore, the results obtained with these methods differed from each other (Figure 2). 
specificity and is based on the reaction of ammonia with phenol and sodium hypochlorite to produce indophenol, which is intensely blue in an alkaline medium (Bolleter et al., 1961; Chaney and Marbach, 1962). In particular, the non-significant intercept (Table 1) reinforced the high specificity of the CICR method because the other nitrogenous compounds present in the medium did not directly interfere with the $\mathrm{N}$ $\mathrm{NH}_{3}$ quantification.

The comparative evaluation of the methods was performed under the assumption that the CICR method is accurate, which was supported by the results obtained with the standard solutions (Table 1). To evaluate the KD method, the 5:1 ratio of the $\mathrm{KOH}$ solution to the rumen fluid samples was adopted because it presented the highest estimate of $\mathrm{N}-\mathrm{NH}_{3}$ recovery between the ratios that produced a complete recovery with the standard solutions (Table 1 and Figure 1). In addition, the 1:10 ratio was evaluated because this ratio was recommended in the original method based on steam distillation (Fenner, 1965).

In spite of the results obtained with the standard solutions (Table 2), the $\mathrm{N}-\mathrm{NH}_{3}$ in the ruminal samples was not detected using the 1:10 ratio of $\mathrm{KOH}$ solution to rumen fluid, which seems to indicate deficiency with regard to acid neutralization.

Table 2. Average contents of ammonia nitrogen $\left(\mathrm{N}-\mathrm{NH}_{3}, \mathrm{mg} / \mathrm{dL}\right)$ in the standard solutions obtained using the two analytical methods

\begin{tabular}{|c|c|c|c|c|c|}
\hline \multirow[b]{2}{*}{ Method } & \multicolumn{5}{|c|}{ 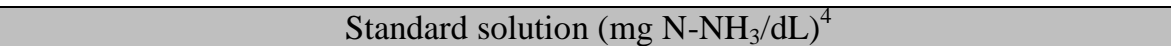 } \\
\hline & 0 & 3 & 6 & 12 & 24 \\
\hline \multicolumn{6}{|l|}{$\mathrm{KD}^{12}$} \\
\hline $10: 1$ & $2.60 \pm 0.09$ & $5.46 \pm 0.05$ & $8.09 \pm 0.06$ & $13.80 \pm 0.07$ & $24.97 \pm 0.08$ \\
\hline $7.5: 1$ & $2.69 \pm 0.05$ & $5.63 \pm 0.06$ & $8.09 \pm 0.04$ & $13.45 \pm 0.09$ & $26.34 \pm 1.24$ \\
\hline $5: 1$ & $2.25 \pm 0.03$ & $5.13 \pm 0.03$ & $8.07 \pm 0.25$ & $14.41 \pm 0.79$ & $25.38 \pm 1.09$ \\
\hline $2.5: 1$ & $2.09 \pm 0.03$ & $4.80 \pm 0.04$ & $7.57 \pm 0.05$ & $12.92 \pm 0.08$ & $23.82 \pm 0.05$ \\
\hline $1: 1$ & $1.62 \pm 0.05$ & $4.23 \pm 0.07$ & $6.94 \pm 0.03$ & $12.27 \pm 0.06$ & $23.60 \pm 0.19$ \\
\hline $1: 2.5$ & $1.13 \pm 0.03$ & $3.76 \pm 0.06$ & $6.31 \pm 0.06$ & $11.58 \pm 0.03$ & $22.45 \pm 0.14$ \\
\hline $1: 5$ & $0.82 \pm 0.04$ & $3.48 \pm 0.03$ & $6.15 \pm 0.08$ & $11.39 \pm 0.09$ & $22.14 \pm 0.13$ \\
\hline $1: 7.5$ & $0.77 \pm 0.06$ & $3.35 \pm 0.03$ & $6.04 \pm 0.06$ & $11.28 \pm 0.07$ & $22.16 \pm 0.18$ \\
\hline $1: 10$ & $0.47 \pm 0.03$ & $3.29 \pm 0.04$ & $5.93 \pm 0.05$ & $11.43 \pm 0.09$ & $21.90 \pm 0.40$ \\
\hline $\mathrm{CICR}^{3}$ & $0.79 \pm 0.03$ & $3.96 \pm 0.34$ & $6.84 \pm 0.50$ & $11.41 \pm 0.65$ & $24.98 \pm 0.88$ \\
\hline
\end{tabular}

${ }^{1}$ Kjeldahl distillation. ${ }^{2}$ Using different ratios of the $\mathrm{KOH}$ solution to the standard solutions $(\mathrm{mL} / \mathrm{mL}) .{ }^{3}$ Catalyzed indophenol colorimetric reaction. ${ }^{4}$ Mean \pm standard error.

The KD method (5:1 ratio) estimated the $\mathrm{N}-\mathrm{NH}_{3}$ concentrations with higher precision than the CICR method; however, those values were, on average, higher than the values obtained using the CICR method (Table 3).

The intercept for the relationship between the KD (5:1) and CICR methods (Figure 2) for the rumen fluid samples was similar to that obtained when standard solutions were evaluated by the KD method (5:1 ratio; Table 2), which emphasizes the occurrence of deamination of true protein. However, unlike the observations with the standard solutions, the KD did not allow the complete recovery of $\mathrm{N}-\mathrm{NH}_{3}$ in the rumen fluid samples $(\mathrm{P}<0.05$; Figure 2$)$. Such a pattern seems to be plausible because rumen fluid samples are more complex than the standard solutions; the former comprises varied concentrations and proportions of VFA and presents compounds that were not included in the standard solutions (e.g., lactic acid and branchedchain volatile fatty acids).

Despite the differences, $\mathrm{N}-\mathrm{NH}_{3}$ concentrations estimated by the two methods were strongly correlated $(\mathrm{r}=0.9701$; Figure 2). Considering that there are situations where only the KD method could be used, $\mathrm{N}-\mathrm{NH}_{3}$ concentrations estimated by this method could be converted into values that are equivalent to those obtained by the CICR method (Figure 2). Such a conversion could be performed as follows: 
$N-N H_{3}(a)=\frac{\left[N-N H_{3}(K)\right]-\left[N-N H_{3}(d)\right]}{R R}=\frac{\left[N-N H_{3}(K)\right]-2.11}{0.83}$

where $\mathrm{N}-\mathrm{NH}_{3}(\mathrm{a})=$ the adjusted $\mathrm{N}-\mathrm{NH}_{3}$ concentration in rumen fluid $(\mathrm{mg} / \mathrm{dL}) ; \mathrm{N}-\mathrm{NH}_{3}(\mathrm{~K})=$ the $\mathrm{N}-\mathrm{NH}_{3}$ concentration in rumen fluid estimated by the $\mathrm{KD}$ method using a 5:1 ratio of $\mathrm{KOH}$ solution to the rumen fluid sample $(\mathrm{mg} / \mathrm{dL}) ; \mathrm{N}-\mathrm{NH}_{3}(\mathrm{~d})=$ the $\mathrm{N}-\mathrm{NH}_{3}$ arising from the deamination of true protein $(\mathrm{mg} / \mathrm{dL})$; and $\mathrm{RR}=$ the recovery rate of $\mathrm{N}-\mathrm{NH}_{3}$ in the medium.

Table 3. Descriptive statistics for the ammonia nitrogen concentration $(\mathrm{mg} / \mathrm{dL})$ in the rumen fluid samples estimated by the catalyzed indophenol colorimetric reaction (CICR) and Kjeldahl distillation (KD) methods

\begin{tabular}{lcc}
\multirow{2}{*}{\multicolumn{1}{c}{ Statistic }} & \multicolumn{2}{c}{ Method } \\
\cline { 2 - 3 } Mean & CICR & KD $^{1}$ \\
Median & 9.31 & 9.82 \\
Maximum & 7.61 & 6.03 \\
Minimum & 33.88 & 31.70 \\
Standard & 0.17 & 1.75 \\
deviation & 7.07 & 6.03 \\
Relative standard & 75.9 & 61.4 \\
deviation (\%) & \multicolumn{2}{c}{93} \\
n & \multicolumn{2}{c}{ - } \\
1 Using a 5:1 ratio of the KOH solution to the rumen \\
fluid sample.
\end{tabular}

\section{CONCLUSIONS}

The method based on a catalyzed indophenol colorimetric reaction produces accurate estimates of ammonia concentrations in rumen fluid. Conversely, the method based on the Kjeldahl distillation produces biased estimates due to the deamination of true protein and the incomplete recovery of ammonia nitrogen. However, these methods were observed to be strongly correlated. Therefore, the estimates obtained by the Kjeldahl distillation using a 5:1 ratio of potassium hydroxide solution $(2 \mathrm{~mol} / \mathrm{L})$ to the rumen fluid sample could be adjusted to avoid such biases. A model to adjust the ammonia concentration obtained by the Kjeldahl distillation is presented in this work.

\section{REFERENCES}

BOLLETER, W.T.; BUSHMAN, C.J.; TIDWELL, P.W. Spectrophotometric determination of ammonia as indophenol. Anal. Chem., v.33, p.592-594, 1961.

CHANEY, A.L.; MARBACH, E.P. Modified reagents for determination of urea and ammonia. Clin. Chem., v.8, p.130-132, 1962.

COSTA, V.A.C.; DETMANN, E.; PAULINO, M.F. et al. Digestibilidade e balanço nitrogenado em bovinos em pastejo no período das águas suplementados com nitrogênio não-protéico e/ou proteína verdadeira. Rev. Bras. Zootec., v.40, p.2815-2826, 2011.

DETMANN, E.; PAULINO, M.F.; MANTOVANI, H.C. et al. Parameterization of ruminal fibre degradation in low-quality tropical forage using Michaelis-Menten kinetics. Liv. Sci., v.126, p.136-146, 2009.

FENNER, H. Method for determining total volatile bases in rumen fluid by steam distillation. J. Dairy Sci., v.48, p.249-251, 1965.

McDOUGALL, E.I. Studies on ruminal saliva. 1. The composition and output of sheep's saliva. $J$. Biochem., v.43, p.99-109, 1949.

RUSSELL, J.B. Rumen microbiology and its role in ruminant nutrition. Ithaca: James B. Russell, 2002. 119p.

SOUZA, M.A.; DETMANN, E.; PAULINO, M.F. et al. Intake, digestibility and rumen dynamics of neutral detergent fiber in cattle fed low-quality tropical forage and supplemented with nitrogen and/or starch. Trop. Anim. Health Prod., v.42, p.1299-1310, 2010.

THOMAS, S; RUSSELL, J.B. The effect of cellobiose, glucose, and cellulose on the survival of Fibrobacter succinogenes A3C cultures grown under ammonia limitation. Curr. Microb., v.48, p.219-223, 2004. 